\title{
Of mice, macaques and men: scaling of virus dynamics and immune responses
}

\author{
Christian L. Althaus * \\ Institute of Social and Preventive Medicine (ISPM), Faculty of Medicine, University of Bern, Bern, Switzerland
}

Keywords: allometric scaling, viral dynamics, viral replication, immune escape, cellular immune response, mice, macaques, humans

In this Opinion piece, I argue that the dynamics of viruses and the cellular immune response depend on the body size of the host. I use allometric scaling theory to interpret observed quantitative differences in the infection dynamics of lymphocytic choriomeningitis virus (LCMV) in mice (Mus musculus), simian immunodeficiency virus (SIV) in rhesus macaques (Macaca mulatta) and human immunodeficiency virus (HIV) in humans.

It is well-known that the average metabolic rate of cells is typically lower in larger species (Kleiber, 1932). Allometric theory predicts that the total metabolic rate of an organism scales approximately as $M^{3 / 4}$, with $M$ being the body mass (West et al., 1997). Assuming invariant size and volume of cells between species, the metabolic rate of a single cell then scales as $M^{-1 / 4}$. Other properties such as the lifespan of an animal or the number of certain cell types have also been

OPEN ACCESS

Edited by:

Hirofumi Akari,

Kyoto University, Japan

Reviewed by:

Melanie E. Moses,

University of New Mexico, USA

Hiroyuki Yamamoto,

AIDS Research Center, National

Institute of Infectious Diseases, Japan

*Correspondence:

Christian L. Althaus,

christian.althaus@alumni.ethz.ch

Specialty section:

This article was submitted to

Virology,

a section of the journal

Frontiers in Microbiology

Received: 19 January 2015 Accepted: 09 April 2015

Published: 23 April 2015

Citation:

Althaus CL (2015) Of mice, macaques and men: scaling of virus dynamics and immune responses. Front. Microbiol. 6:355.

doi: 10.3389/fmicb.2015.00355 found to depend on body size (Peters, 1983; Schmidt-Nielsen, 1984; Calder, 1996; Savage et al., 2007). In host-pathogen systems, the following three aspects could underlie allometric scaling laws (Wiegel and Perelson, 2004; Cable et al., 2007; Banerjee and Moses, 2010). First, the metabolic rate will affect the rate at which cells synthesize DNA and proteins and could therefore influence the replication rate of viruses. Second, quantitative processes of the cellular immune response could be affected by allometric scaling. Third, the interaction between viral replication rates and the dynamics of immune responses could result in differences in the time to disease progression between host species.

Insights of the within-host dynamics of HIV is often based on experimental studies in macaques. Despite being a non-natural host, macaques can be infected with SIV, the simian counterpart of HIV. The viral turnover within a host has been found to be more rapid in macaques than in humans, with estimated half-lives of virus-producing cells of 0.5 days and 0.7 days, respectively (Markowitz et al., 2003; Brandin et al., 2006). In this light, it is interesting to compare the dynamics at which immune escape variants evade recognition from $\mathrm{CD}^{+}$cytotoxic T lymphocyte (CTL) responses in the two host species. Asquith and McLean (2007) showed that escape rates in macaques are about twice as fast as in humans, and suggested more efficient CTL-mediated killing of infected cells in macaques. An alternative hypothesis would be that the rate of immune escape depends on the overall viral turnover (Althaus and De Boer, 2012). With a 10-fold difference in body mass between humans $(\sim 70 \mathrm{~kg})$ and macaques $(\sim 7 \mathrm{~kg})$, allometric scaling predicts a 1.8 -fold difference in the metabolic rate of a single cell between the two species. This factor is close to the reported 2-fold difference in escape rates and the 1.4-fold difference in the viral turnover between humans and macaques. This suggests that the metabolic rate could indeed directly affect the rate of virus replication and indirectly influence the rate of immune escape. However, it is worth noting that rates of CTL escape show substantial variation within host species and are generally faster during the acute phase of infection compared to the chronic phase (O'Connor et al., 2002; Asquith et al., 2006; Althaus and De Boer, 2008). 
Previous studies have investigated how quantitative processes of the cellular immune response could be affected by allometric scaling. In the case of $\mathrm{T}$ cell responses, Wiegel and Perelson (2004) derived some general principles on how the number of naive $\mathrm{T}$ cells scales with body size. Lymphocyte trafficking, i.e., the circulation of $\mathrm{T}$ cells through blood, tissues and the lymphatic system in order to recognize antigen and eliminate virusinfected cells, has also been suggested to underlie general scaling laws (Perelson and Wiegel, 2009). Scaling principles could also be reflected in the varying life spans of naive and memory $\mathrm{T}$ cells between mice and men (De Boer and Perelson, 2013). In addition, the proliferation rate of $\mathrm{CD}^{+} \mathrm{T}$ cell responses during the acute phase of an infection could be linked to the metabolic rate of the host. $\mathrm{CD}^{+} \mathrm{T}$ cells have been found to expand rapidly with a rate of around 2.0 per day after LCMV infection in mice (De Boer et al., 2001, 2003; Althaus et al., 2007). The CD8 ${ }^{+}$T cell kinetics in those studies was measured for acute LCMV infection with the Armstrong strain. Other clones or infection models can cause persistent infection (Recher et al., 2007; Mueller et al., 2007), but the proliferation rates of $\mathrm{CD}^{+}{ }^{+} \mathrm{T}$ cells during the acute phase of infection appear to be similar (Althaus et al., 2007). The expansion rate of $\mathrm{CD}^{+} \mathrm{T}$ cell responses upon SIV-infection in macaques is only about 1.0 per day (Davenport et al., 2004) and suggests a two-fold difference in proliferation rates between the two species. Allometric theory would predict a 4.3 -fold difference between the metabolic rates of a single cell in mice $(\sim 20 \mathrm{~g})$ and macaques $(\sim 7 \mathrm{~kg})$. Hence, differences in the metabolic rate alone cannot account for the different proliferation rates of $\mathrm{CD} 8^{+} \mathrm{T}$ cell responses between the two species.

The time to acquired immunodeficiency syndrome (AIDS) during HIV and SIV infection can be used as a quantity for disease progression. The wide variation of this rate in HIV-infected humans, ranging from years to decades (Fraser et al., 2007), makes it difficult to compare it to the more rapid disease progression of 1 to 2 years in SIV-infected macaques (Kestler et al., 1990). Cable et al. (2007) found that disease progression to symptoms and to death in a small set of pathogens in different host species scales with $M^{-1 / 4}$. It seems unlikely that progression to AIDS during HIV and SIV infection scales according to this law, as that would suggest a 1.8 -fold difference only. If disease progression were directly proportional to body mass, i.e., isometric, we would expect a 10-fold difference which seems to be more consistent with observed progression rates in humans and macaques.

\section{References}

Althaus, C. L., and De Boer, R. J. (2008). Dynamics of immune escape during HIV/SIV infection. PLoS Comput. Biol. 4:e1000103. doi: 10.1371/journal.pcbi. 1000103

Althaus, C. L., and De Boer, R. J. (2012). Impaired immune evasion in HIV through intracellular delays and multiple infection of cells. Proc. Biol. Sci. 279, 3003-3010. doi: 10.1098/rspb. 2012.0328

Althaus, C. L., Ganusov, V. V., and De Boer, R. J. (2007). Dynamics of CD8+ $\mathrm{T}$ cell responses during acute and chronic lymphocytic choriomeningitis virus infection. J. Immunol. 179, 2944-2951. doi: 10.4049/jimmunol.179. 5.2944
It is important to note that host genetics can play a significant role in suppressing SIV replication and establishing a persistent infection (Kirmaier et al., 2010), and is strongly associated with disease progression in HIV (Fellay et al., 2007). An independent marker of disease progression in HIV and SIV is the set-point viral load (Watson et al., 1997), which might be influenced by the viral replication rate. Thus, it remains open whether there is an allometric relationship for the time to disease progression during HIV and SIV infection, and what exponent it would have.

In summary, there are indications that viral replication and the proliferation of $\mathrm{CD}^{+} \mathrm{T}$ cell responses are slower in larger animals. Whether this influences the ability of the cellular immune responses to eradicate viruses during the acute phase of an infection remains unclear. Others have argued that the response rate of immune systems does not change systematically with body size. Instead, the sub-modular architecture of the immune system, where the number and size of lymph nodes increase sublinearly with body size, could balance the tradeoff between the local detection of pathogens and the global host response (Banerjee and Moses, 2010).

Discrepancies between experimental findings of the mice and human immune system have been described and illustrate that using mice as preclinical models for the study of human diseases can be challenging (Mestas and Hughes, 2004). Besides those differences that could be a result of separate evolution, I have highlighted some apparent quantitative differences between the dynamics of viruses and immune responses in mice, macaques and men. Those suggest that allometric scaling principles should be considered for the interpretation of observed differences in the infection dynamics between host species. Precise quantitative measurements of virus and immune response dynamics in different host species are scarce. This poses a problem for investigating scaling relationship in host-pathogen systems that should be addressed by both experimentalists and theoretical biologists. Only additional data on the kinetics of virus replication and the dynamics of $\mathrm{T}$ cell responses in different host species will allow to shed more light on the question whether the nature of viral infections is affected by the body size of their hosts.

\section{Funding}

CA was supported through an Ambizione grant from the Swiss National Science Foundation (grant 136737).

Asquith, B., Edwards, C., Lipsitch, M., and McLean, A. (2006). Inefficient cytotoxic T lymphocyte-mediated killing of HIV-1-infected cells in vivo. PLoS Biol. 4:e90. doi: 10.1371/journal.pbio.0040090

Asquith, B., and McLean, A. (2007). In vivo CD8+ T cell control of immunodeficiency virus infection in humans and macaques. Proc. Natl. Acad. Sci. U.S.A. 104, 6365-6370. doi: 10.1073/pnas.0700666104

Banerjee, S., and Moses, M. (2010). Scale invariance of immune system response rates and times: perspectives on immune system architecture and implications for artificial immune systems. Swarm Intell. 4, 301-318. doi: 10.1007/s11721010-0048-2

Brandin, E., Thorstensson, R., Bonhoeffer, S., and Albert, J. (2006). Rapid viral decay in simian immunodeficiency virus-infected macaques receiving quadruple antiretroviral therapy. J. Virol. 80, 9861-9864. doi: 10.1128/JVI.00394-06 
Cable, J. M., Enquist, B. J., and Moses, M. E. (2007). The allometry of hostpathogen interactions. PLoS ONE 2:e1130. doi: 10.1371/journal.pone.0001130

Calder, W. A. (1996). Size, Function, and Life History. Mineola, NY: Dover Publications.

Davenport, M., Ribeiro, R., and Perelson, A. (2004). Kinetics of virus-specific $\mathrm{CD} 8+\mathrm{T}$ cells and the control of human immunodeficiency virus infection. J. Virol. 78, 10096-10103. doi: 10.1128/JVI.78.18.10096-10103.2004

De Boer, R., Homann, D., and Perelson, A. (2003). Different dynamics of CD4+ and CD8+ $\mathrm{T}$ cell responses during and after acute lymphocytic choriomeningitis virus infection. J. Immunol. 171, 3928-3935. doi: 10.4049/jimmunol.171. 8.3928

De Boer, R., Oprea, M., Antia, R., Murali-Krishna, K., Ahmed, R., and Perelson, A. (2001). Recruitment times, proliferation, and apoptosis rates during the CD8(+) T-cell response to lymphocytic choriomeningitis virus. J. Virol. 75, 10663-10669. doi: 10.1128/JVI.75.22.10663-10669.2001

De Boer, R. J., and Perelson, A. S. (2013). Quantifying T lymphocyte turnover. J. Theor. Biol. 327, 45-87. doi: 10.1016/j.jtbi.2012.12.025

Fellay, J., Shianna, K. V., Ge, D., Colombo, S., Ledergerber, B., Weale, M., et al. (2007). A whole-genome association study of major determinants for host control of HIV-1. Science 317, 944-947. doi: 10.1126/science.1143767

Fraser, C., Hollingsworth, T. D., Chapman, R., de Wolf, F., and Hanage, W. P. (2007). Variation in HIV-1 set-point viral load: epidemiological analysis and an evolutionary hypothesis. Proc. Natl. Acad. Sci. U.S.A. 104, 17441-17446. doi: 10.1073/pnas.0708559104

Kestler, H., Kodama, T., Ringler, D., Marthas, M., Pedersen, N., Lackner, A., et al. (1990). Induction of AIDS in rhesus monkeys by molecularly cloned simian immunodeficiency virus. Science 248, 1109-1112. doi: 10.1126/science.2160735

Kirmaier, A., Wu, F., Newman, R. M., Hall, L. R., Morgan, J. S., O'Connor, S., et al. (2010). TRIM5 suppresses cross-species transmission of a primate immunodeficiency virus and selects for emergence of resistant variants in the new species. PLoS Biol. 8:e1000462. doi: 10.1371/journal.pbio.1000462

Kleiber, M. (1932). Body size and metabolism. Hilgardia 6, 315-353. doi: 10.3733/hilg.v06n11p315

Markowitz, M., Louie, M., Hurley, A., Sun, E., Di Mascio, M., Perelson, A. S., et al. (2003). A novel antiviral intervention results in more accurate assessment of human immunodeficiency virus type 1 replication dynamics and T-cell decay in vivo. J. Virol. 77, 5037-5038. doi: 10.1128/JVI.77.8.5037-5038.2003

Mestas, J., and Hughes, C. C. W. (2004). Of mice and not men: differences between mouse and human immunology. J. Immunol. 172, 2731-2738. doi: 10.4049/jimmunol.172.5.2731
Mueller, S. N., Matloubian, M., Clemens, D. M., Sharpe, A. H., Freeman, G. J., Gangappa, S., et al. (2007). Viral targeting of fibroblastic reticular cells contributes to immunosuppression and persistence during chronic infection. Proc. Natl. Acad. Sci. U.S.A. 104, 15430-15435. doi: 10.1073/pnas.0702579104

O'Connor, D. H., Allen, T. M., Vogel, T. U., Jing, P., DeSouza, I. P., Dodds, E., et al. (2002). Acute phase cytotoxic T lymphocyte escape is a hallmark of simian immunodeficiency virus infection. Nat. Med. 8, 493-499. doi: 10.1038/nm0502-493

Perelson, A. S., and Wiegel, F. W. (2009). Scaling aspects of lymphocyte trafficking. J. Theor. Biol. 257, 9-16. doi: 10.1016/j.jtbi.2008.11.007

Peters, R. H. (1983). The Ecological Implications of Body Size. Cambridge: Cambridge University Press.

Recher, M., Lang, K. S., Navarini, A., Hunziker, L., Lang, P. A., Fink, K., et al. (2007). Extralymphatic virus sanctuaries as a consequence of potent T-cell activation. Nat. Med. 13, 1316-1323. doi: 10.1038/nm1670

Savage, V. M., Allen, A. P., Brown, J. H., Gillooly, J. F., Herman, A. B., Woodruff, W. H., et al. (2007). Scaling of number, size, and metabolic rate of cells with body size in mammals. Proc. Natl. Acad. Sci. U.S.A. 104, 4718-4723. doi: 10.1073/pnas.0611235104

Schmidt-Nielsen, K. (1984). Scaling, Why Is Animal Size So Important? Cambridge: Cambridge University Press.

Watson, A., Ranchalis, J., Travis, B., McClure, J., Sutton, W., Johnson, P. R., et al. (1997). Plasma viremia in macaques infected with simian immunodeficiency virus: plasma viral load early in infection predicts survival. J. Virol. 71, 284-290.

West, G. B., Brown, J. H., and Enquist, B. J. (1997). A general model for the origin of allometric scaling laws in biology. Science 276, 122-126. doi: 10.1126/science.276.5309.122

Wiegel, F. W., and Perelson, A. S. (2004). Some scaling principles for the immune system. Immunol. Cell Biol. 82, 127-131. doi: 10.1046/j.0818-9641.2004.01229.x

Conflict of Interest Statement: The author declares that the research was conducted in the absence of any commercial or financial relationships that could be construed as a potential conflict of interest.

Copyright (c) 2015 Althaus. This is an open-access article distributed under the terms of the Creative Commons Attribution License (CC BY). The use, distribution or reproduction in other forums is permitted, provided the original author (s) or licensor are credited and that the original publication in this journal is cited, in accordance with accepted academic practice. No use, distribution or reproduction is permitted which does not comply with these terms. 